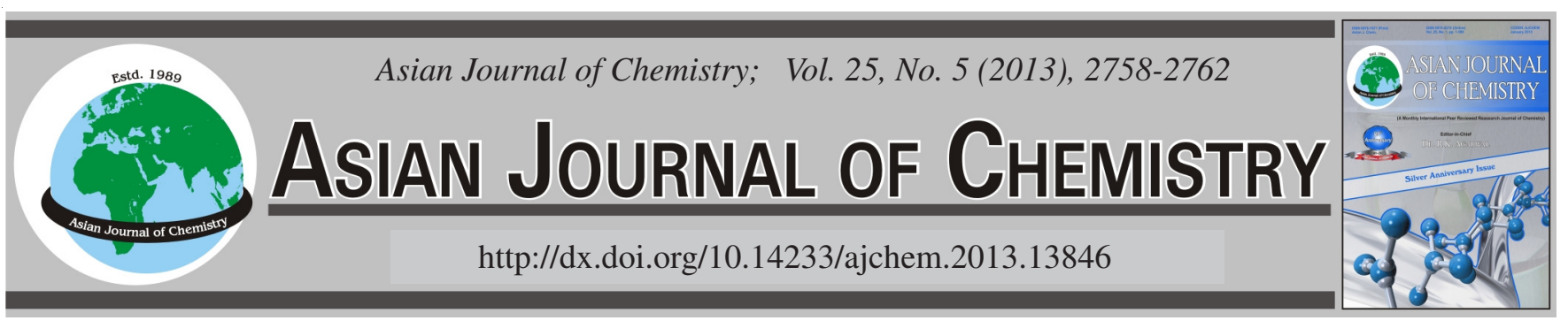

\title{
Synthesis, Characterization and Photochromic Properties of Novel Spirooxazines
}

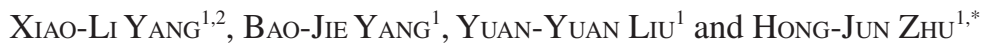

${ }^{1}$ College of Science, Nanjing University of Technology, Nanjing, P.R. China

${ }^{2}$ School of Material Engineering, Jinling Institute of Technology, Nanjing, P.R. China

*Corresponding author: Fax: +86 25 83587428; Tel: +86 25 83172358; E-mail: zhuhjnjut@ hotmail.com

Key Words: Spirooxazine, Merocyanine, Photochromism, Heterocycle, Esterification.

ᄂ - - - - - - - - - - - - - - - - - - - - - - - - - - - - -

\section{INTRODUCTION}

Spirooxanzines are a well-known class of photochromic compounds due to their superior photochromic prosperties, such as photo-fatigue resistance and photocolouration ${ }^{1-3}$, which facilitate their application in memory devices, optical switches, displays, chemical sensors and ophthalmic plastic lenses ${ }^{4-7}$. The photochromism of spirooxazines is attributable to a heterolytic spiro-C-O bond cleavage via UV irradiation that generates the coloured merocyanine form (MC). The merocyanine form form reverts to the closed colourless form (SO) either thermally or photochemically (Scheme-I) ${ }^{8-10}$. The reported work are quite interesting, however, the commercial application of most spirooxazines has been severely restricted in the past decades by the unacceptable thermal decoloration process of the coloured photomerocyanine species. In this context, the development of novel photochromic molecule which features acceptable relaxation time and the further study of the photophysical properties, photochromic behaviours and structure-property relationships present an interesting challenge.

1,3,3-Trimethyl spiro[2H]-indol-2,3'-[3H]-naphtho[2,1b] $[1,4]$ oxazine is a very typical spirooxazine compound which has attracted a great interest by virtue of their excellent photochromic properties ${ }^{10}$. In this work, a series of novel spirooxazine compounds (1b-1c, $\mathbf{2 b - 2 f})$ based on 1,3,3trimethyl spiro-[2H]-indol-2,3'-[3H]-naphtho[2,1-b][1,4]oxazine were designed and synthesized. Compound 1a and 2a

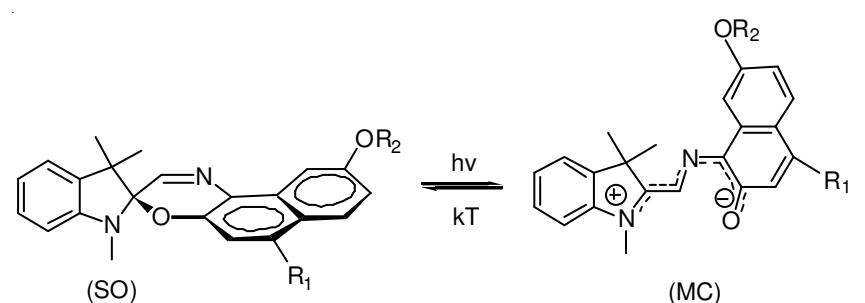

Scheme-I: Photochromic interconversion (hv) and thermal relexation (kT) of the spirooxazine SO and merocyanine merocyanine form states of compounds

have been reported in the literature ${ }^{11}$ and were synthesized as reference compounds. Their photochromic behaviours and thermal stability have been investigated with the aim of understanding the structure-physical property relationships and developing potential photochromic materials.

\section{EXPERIMENTAL}

All reagents were purchased from commercial sources and used without further purification unless otherwise noted. 1-Nitroso-2,7-dihydroxynaphthalene was synthesized according to the literature methods ${ }^{3}$. Melting points were measured on an X-4 microscope electrothermal apparatus and remained uncorrected. ${ }^{1} \mathrm{H}$ and ${ }^{13} \mathrm{C}$ NMR spectra were obtained in DMSO$d_{6}$ or $\mathrm{CDCl}_{3}$ using a Bruker AV-500 spectrometer at $500 \mathrm{MHz}$ or a Bruker AV-300 spectrometer at $300 \mathrm{MHz}$. Chemical shifts 
were reported in $\delta(\mathrm{ppm})$ relative to tetramethylsilane, which was used as the internal standard. Fourier transformation infrared (FTIR) spectra were recorded in $\mathrm{KBr}$ pellets using an FTIR spectrometer (NICOLET IS10). Elemental analyses were carried out on a Vario EL III elemental analyzer. Optical absorption spectra were recorded using a CARY 1101 UVVIS spectrophotometer.

General procedure for synthesis of compounds 1a-1c: 1-Nitroso-2,7-dihydroxynaphthalene (3.78 g, $20 \mathrm{mmol})$ was dissolved in methanol $(200 \mathrm{~mL})$ and heated to reflux under nitrogen, then treated with a solution of $\mathrm{R}_{1} \mathrm{H}(40 \mathrm{mmol})$ in methanol $(10 \mathrm{~mL})$. The resulting mixture was heated to reflux for $5 \mathrm{~h}$ and then treated, over a $5 \mathrm{~min}$ period, with a solution of 1,3,3-trimethyl-2-methyleneindoline (3.46 g, $20 \mathrm{mmol}$ ) in methanol $(10 \mathrm{~mL})$. The progress of this reaction was monitored by TLC, which indicated completion of the reaction after $36 \mathrm{~h}$. Then the solution was cooled and the brown solid was separated by filtering. The residue was purified via column chromatography (silica, petroleum ether/ethyl acetate, $1 / 3, \mathrm{v} / \mathrm{v})$.

1,3,3-Trimethyl-9'-hydroxy-spiro[indoline-2,3' $(3 H)$ naphtho[2,1-b][1,4]oxazine] (1a): Gray solid, yield: $51.2 \%$, m.p. $167-170^{\circ} \mathrm{C}$ (lit.: m.p. $\left.167-168^{\circ} \mathrm{C}\right)^{12}$. IR (KBr, $v_{\max }, \mathrm{cm}^{-1}$ ): 3330, 2970, 1625, 1480, 1450, 1360, 1235, 1090, 1190, 980, 897, 835, 844, 744. Anal. calcd. (\%) for $\mathrm{C}_{22} \mathrm{H}_{20} \mathrm{~N}_{2} \mathrm{O}_{2}$ : C, 76.72; H, 5.85; N 8.13. Found (\%): C,77.02; H, 5.82; N, 8.16.

1,3,3-Trimethyl-6'-morpholino-9' -hydroxy-spiro[indoline-2,3'(3H)naphtho[2,1-b][1,4] oxazine] (1b): Blue solid, yield: $3.6 \%$, m.p. $246-248^{\circ} \mathrm{C}$. IR $\left(\mathrm{KBr}, \mathrm{v}_{\max }, \mathrm{cm}^{-1}\right)$ : 3400 , 2960, 1620, 1460, 1360, 1230, 1110, 1150, 982, 825, 742. ${ }^{1} \mathrm{H}$ NMR (DMSO, $500 \mathrm{MHz}): \delta 9.79(1 \mathrm{H}, \mathrm{s}, \mathrm{OH}), 7.86(1 \mathrm{H}, \mathrm{d}$, $J=8.9 \mathrm{~Hz}, \mathrm{ArH}), 7.73$ (1H, s, 2'-H), 7.66 (1H, s, ArH), 7.16$7.12(2 \mathrm{H}, \mathrm{m}, \mathrm{ArH}), 6.93(1 \mathrm{H}, \mathrm{d}, J=8.2 \mathrm{~Hz}, \mathrm{ArH}), 6.82(1 \mathrm{H}, \mathrm{t}$, $J=7.3 \mathrm{~Hz}, \mathrm{ArH}), 6.63(1 \mathrm{H}, \mathrm{d}, J=7.6 \mathrm{~Hz}, \mathrm{ArH}), 6.41(1 \mathrm{H}, \mathrm{s}$, ArH), $3.80\left(4 \mathrm{H}, \mathrm{t}, J=4.3 \mathrm{~Hz}, 2 \mathrm{CH}_{2}\right), 2.95(4 \mathrm{H}, \mathrm{t}, J=4.3 \mathrm{~Hz}$, $\left.2 \mathrm{CH}_{2}\right), 2.67\left(3 \mathrm{H}, \mathrm{s}, \mathrm{CH}_{3}\right), 1.26\left(6 \mathrm{H}, \mathrm{s}, \mathrm{CH}_{3}\right)$. Anal. calcd. (\%) for $\mathrm{C}_{26} \mathrm{H}_{27} \mathrm{~N}_{3} \mathrm{O}_{3}$ : C, 72.71; $\mathrm{H}, 6.34 ; \mathrm{N} 9.78$. Found (\%): C,72.59; $\mathrm{H}, 6.32 ; \mathrm{N}, 9.81$.

1,3,3-Trimethyl-6'-indolino-9'-hydroxy-spiro[indoline2,3'(3H)naphtho[2,1-b][1,4]oxazine] (1c): Grey-green solid, yield: $3.5 \%$, m.p. $124-126{ }^{\circ} \mathrm{C}$. IR $\left(\mathrm{KBr}, \mathrm{v}_{\max }, \mathrm{cm}^{-1}\right)$ : 3420 , 2960, 1620, 1480, 1460, 1260, 1030, 1160, 982, 748. ${ }^{1} \mathrm{H}$ NMR (DMSO, $500 \mathrm{MHz}): \delta 9.89(1 \mathrm{H}, \mathrm{s}, \mathrm{OH}), 7.79(1 \mathrm{H}, \mathrm{d}, J=2.5$ $\mathrm{Hz}, \mathrm{ArH}), 7.72$ (1H, s, 2'-H), 7.65 (1H, d, $J=9.0 \mathrm{~Hz}, \mathrm{ArH})$, 7.13-7.10 (4H, m, ArH), 6.90 (1H, t, $J=2.6 \mathrm{~Hz}, \mathrm{ArH}), 6.81-$ $6.64(3 \mathrm{H}, \mathrm{m}, \mathrm{ArH}), 6.61(1 \mathrm{H}, \mathrm{d}, J=7.7 \mathrm{~Hz}, \mathrm{ArH}), 6.08(1 \mathrm{H}, \mathrm{d}$, $J=7.8 \mathrm{~Hz}, \mathrm{ArH}), 3.86\left(2 \mathrm{H}, \mathrm{t}, J=8.5 \mathrm{~Hz}, \mathrm{CH}_{2}\right), 3.08(2 \mathrm{H}, \mathrm{t}$, $\left.J=8.5 \mathrm{~Hz}, \mathrm{CH}_{2}\right), 2.67\left(3 \mathrm{H}, \mathrm{s}, \mathrm{CH}_{3}\right), 1.27\left(3 \mathrm{H}, \mathrm{s}, \mathrm{CH}_{3}\right), 1.26$ $\left(3 \mathrm{H}, \mathrm{s}, \mathrm{CH}_{3}\right)$. Anal. calcd. (\%) for $\mathrm{C}_{30} \mathrm{H}_{27} \mathrm{~N}_{3} \mathrm{O}_{2}: \mathrm{C}, 78.07 ; \mathrm{H}$, $5.90 ;$ N, 9.10. Found (\%) C, 77.94; H, 5.88; N, 9.13.

General procedure for synthesis of compounds 2a-2f: In a $250 \mathrm{~mL}$ three-necked flask equipped with a temperature probe, dropping funnel and magnetic stirrer, 1a-1c $(2 \mathrm{mmol})$ was dissolved in a mixture of benzene $(140 \mathrm{~mL})$ and $1,4-$ dioxane $(20 \mathrm{~mL})$. At $5{ }^{\circ} \mathrm{C}, \mathrm{R}_{2} \mathrm{COCl}(20 \mathrm{mmol}$ in benzene, $10 \mathrm{~mL}$ ) was added dropwise over a period of $0.5 \mathrm{~h}$. After continuous stirring for $10 \mathrm{~h}$ at room temperature, a small amount of insoluble matter was filtered off and the solution was removed in vacuo. The residue obtained was recrystallised from hot methyl alcohol to obtain $\mathbf{2 a - 2 f}$ as pure products.

1,3,3-Trimethyl-9'-methacryloyloxy-spiro[indoline2,3'(3H) naphtho[2,1-b][1,4] oxazine] (2a): Gray solid, yield: $97.6 \%$, m.p. $151-153{ }^{\circ} \mathrm{C}$. IR $\left(\mathrm{KBr}, \mathrm{v}_{\max }, \mathrm{cm}^{-1}\right): 3047,2971$, 1730, 1630, 1480,1440, 1360, 1256, 1080, 1170, 1120, 978, 903, 823, 748. ${ }^{1} \mathrm{H} \mathrm{NMR}\left(\mathrm{CDCl}_{3}, 500 \mathrm{MHz}\right): \delta 8.27(1 \mathrm{H}, \mathrm{d}, J=$ $2.3 \mathrm{~Hz}, \mathrm{ArH}), 7.76$ (1H, d, J = 8.9 Hz, ArH), 7.71 ( 1H, s, 2'H), $7.65(1 \mathrm{H}, \mathrm{d}, J=8.9 \mathrm{~Hz}, \mathrm{ArH}), 7.23-7.17(2 \mathrm{H}, \mathrm{m}, \mathrm{ArH})$, $7.08(1 \mathrm{H}, \mathrm{d}, J=7.1 \mathrm{~Hz}, \mathrm{ArH}), 6.99(1 \mathrm{H}, \mathrm{d}, J=8.9 \mathrm{~Hz}, \mathrm{ArH})$, $6.90(1 \mathrm{H}, \mathrm{t}, J=7.4 \mathrm{~Hz}, \mathrm{ArH}), 6.58(1 \mathrm{H}, \mathrm{d}, J=7.7 \mathrm{~Hz}, \mathrm{ArH})$, $6.41(1 \mathrm{H}, \mathrm{s}, \mathrm{CH}), 5.78(1 \mathrm{H}, \mathrm{s}, \mathrm{CH}), 2.76\left(3 \mathrm{H}, \mathrm{s}, \mathrm{CH}_{3}\right), 2.11$ $\left(3 \mathrm{H}, \mathrm{s}, \mathrm{CH}_{3}\right), 1.35\left(6 \mathrm{H}, \mathrm{s}, \mathrm{CH}_{3}\right) .{ }^{13} \mathrm{C}$ NMR (DMSO, $\left.300 \mathrm{MHz}\right)$ : $\delta$ 18.0, 20.4, 25.1, 29.2, 51.5, 98.4, 107.1, 1123, 116.5, 119.5, 119.6, 121.5, 122.2, 126.8, 127.8, 127.8, 129.7, 130.2, 130.9, 135.3, 135.4, 144.4, 147.2, 149.6, 151.6, 165.4. Anal. calcd. (\%) for $\mathrm{C}_{26} \mathrm{H}_{24} \mathrm{~N}_{2} \mathrm{O}_{3}: \mathrm{C}, 75.71 ; \mathrm{H}, 5.86 ; \mathrm{N}, 6.79$. Found (\%) $\mathrm{C}$, 75.57; H, 5.84; N, 6.81 .

1,3,3-Trimethyl-9'-benzoyloxy-spiro[indoline-2,3'(3H) naphtho[2,1-b][1,4]oxazine](2b): Gray solid, yield: $96.6 \%$, m.p. $214-216^{\circ} \mathrm{C}$. IR (KBr, $\left.v_{\max }, \mathrm{cm}^{-1}\right)$ : 3047, 2960, 1630, 1480, 1370, 1250, 1060, 1114, 971, 829, 741. ${ }^{1} \mathrm{H} \mathrm{NMR}\left(\mathrm{CDCl}_{3}, 500\right.$ $\mathrm{MHz}): \delta 8.38(1 \mathrm{H}, \mathrm{d}, J=1.9 \mathrm{~Hz}, \mathrm{ArH}), 8.27(2 \mathrm{H}, \mathrm{d}, J=7.2$ $\mathrm{Hz}, \mathrm{ArH}), 7.81(1 \mathrm{H}, \mathrm{d}, J=8.8 \mathrm{~Hz}, \mathrm{ArH}), 7.71\left(1 \mathrm{H}, \mathrm{s}, 2^{\prime}-\mathrm{H}\right)$, $7.64(2 \mathrm{H}, \mathrm{t}, J=7.4 \mathrm{~Hz}, \mathrm{ArH}), 7.54(2 \mathrm{H}, \mathrm{t}, J=7.7 \mathrm{~Hz}, \mathrm{ArH})$, $7.28(1 \mathrm{H}, \mathrm{d}, J=2.2 \mathrm{~Hz}, \mathrm{ArH}), 7.22(1 \mathrm{H}, \mathrm{t}, J=7.7 \mathrm{~Hz}, \mathrm{ArH})$, $7.08(1 \mathrm{H}, \mathrm{d}, J=7.2 \mathrm{~Hz}, \mathrm{ArH}), 7.01(1 \mathrm{H}, \mathrm{d}, J=8.8 \mathrm{~Hz}, \mathrm{ArH})$, $6.90(1 \mathrm{H}, \mathrm{t}, J=7.4 \mathrm{~Hz}, \mathrm{ArH}), 6.58(1 \mathrm{H}, \mathrm{d}, J=7.7 \mathrm{~Hz}, \mathrm{ArH})$, $2.77\left(3 \mathrm{H}, \mathrm{s}, \mathrm{CH}_{3}\right), 1.36\left(3 \mathrm{H}, \mathrm{s}, \mathrm{CH}_{3}\right), 1.35\left(3 \mathrm{H}, \mathrm{s}, \mathrm{CH}_{3}\right)$. Anal. calcd. (\%) for $\mathrm{C}_{29} \mathrm{H}_{24} \mathrm{~N}_{2} \mathrm{O}_{3}$ : C, 77.66; H, 5.39; N, 6.25. Found (\%) C, 77.53; H, 5.38; N, 6.27.

1,3,3-Trimethyl-9' - ( $p$-chlorobenzoyloxy)-spiro[indoline-2,3'(3H)naphtho[2,1-b][1,4]oxazine] (2c): Gray solid, yield: $98.5 \%$, m.p. $234-235^{\circ} \mathrm{C}$. IR (KBr, $\left.v_{\max }, \mathrm{cm}^{-1}\right)$ : 3048, 2961, 1624, 1465, 1362, 1263, 1067, 1116, 975, 848, 753, 680. ${ }^{1} \mathrm{H} \mathrm{NMR}\left(\mathrm{CDCl}_{3}, 500 \mathrm{MHz}\right): \delta 8.37(1 \mathrm{H}, \mathrm{d}, J=1.7$ $\mathrm{Hz}, \mathrm{ArH}), 8.20(2 \mathrm{H}, \mathrm{d}, J=8.4 \mathrm{~Hz}, \mathrm{ArH}), 7.78(1 \mathrm{H}, \mathrm{d}, J=8.8$ $\mathrm{Hz}, \mathrm{ArH}), 7.71$ (1H, s , 2'-H), $7.68(1 \mathrm{H}, \mathrm{d}, J=8.9 \mathrm{~Hz}, \mathrm{ArH})$, $7.51(2 \mathrm{H}, \mathrm{d}, J=8.4 \mathrm{~Hz}, \mathrm{ArH}), 7.26(1 \mathrm{H}, \mathrm{d}, J=2.1 \mathrm{~Hz}, \mathrm{ArH})$, $7.22(1 \mathrm{H}, \mathrm{t}, J=7.6 \mathrm{~Hz}, \mathrm{ArH}), 7.09(1 \mathrm{H}, \mathrm{d}, J=7.2 \mathrm{~Hz}, \mathrm{ArH})$, $7.01(1 \mathrm{H}, \mathrm{d}, J=8.9 \mathrm{~Hz}, \mathrm{ArH}), 6.90(1 \mathrm{H}, \mathrm{t}, J=7.4 \mathrm{~Hz}, \mathrm{ArH})$, $6.58(1 \mathrm{H}, \mathrm{d}, J=7.7 \mathrm{~Hz}, \mathrm{ArH}), 2.76\left(3 \mathrm{H}, \mathrm{s}, \mathrm{CH}_{3}\right), 1.35(6 \mathrm{H}, \mathrm{s}$, $\mathrm{CH}_{3}$ ). ${ }^{13} \mathrm{C}$ NMR (DMSO, $300 \mathrm{MHz}$ ): $\delta 20.4,25.1,29.2,51.5$, 98.5, 107.1, 112.4, 116.6, 119.4, 119.6, 121.4, 122.3, 126.9, 127.8, 127.8, 129.1, 129.7, 130.2, 130.9, 131.7, 135.4, 138.99, 144.4, 147.2, 149.5, 151.7, 163.9. Anal. calcd. (\%) for $\mathrm{C}_{29} \mathrm{H}_{23} \mathrm{ClN}_{2} \mathrm{O}_{3}: \mathrm{C}, 72.12 ; \mathrm{H}, 4.80 ; \mathrm{N}, 5.80$. Found (\%) C, 71.98; H, 4.78; N, 5.82.

1,3,3-Trimethyl-9'-methacryloyloxy-6' -morpholinospiro[indoline-2,3'(3H) naphtho[2,1-b][1,4]oxazine] (2d): Gray solid, yield: $78.4 \%$, m.p. $193-195^{\circ} \mathrm{C}$. IR $\left(\mathrm{KBr}, v_{\max }, \mathrm{cm}^{-1}\right)$ : 3050, 2960, 1730, 1620, 1490, 1260, 1030, 1135, 978, 742. ${ }^{1} \mathrm{H} \mathrm{NMR}\left(\mathrm{CDCl}_{3}, 500 \mathrm{MHz}\right): \delta 8.16(1 \mathrm{H}, \mathrm{d}, J=2.4 \mathrm{~Hz}, \mathrm{ArH})$, $8.08(1 \mathrm{H}, \mathrm{d}, J=9.1 \mathrm{~Hz}, \mathrm{ArH}), 7.73\left(1 \mathrm{H}, \mathrm{s}, 2^{\prime}-\mathrm{H}\right), 7.24(1 \mathrm{H}, \mathrm{d}$, $J=2.4 \mathrm{~Hz}, \mathrm{ArH}), 7.17-7.10(2 \mathrm{H}, \mathrm{m}, \mathrm{ArH}), 6.84(1 \mathrm{H}, \mathrm{t}, J=7.5$ $\mathrm{Hz}, \mathrm{ArH}), 6.69$ (1H, s, ArH), 6.65 (1H, d, $J=7.6 \mathrm{~Hz}, \mathrm{ArH})$, $6.35(1 \mathrm{H}, \mathrm{s}, \mathrm{CH}), 5.94(1 \mathrm{H}, \mathrm{s}, \mathrm{CH}), 3.82(4 \mathrm{H}, \mathrm{t}, J=4.4 \mathrm{~Hz}$, $\left.2 \mathrm{CH}_{2}\right), 3.01\left(4 \mathrm{H}, \mathrm{t}, J=4.4 \mathrm{~Hz}, 2 \mathrm{CH}_{2}\right), 2.70\left(3 \mathrm{H}, \mathrm{s}, \mathrm{CH}_{3}\right), 2.06$ 
$\left(3 \mathrm{H}, \mathrm{s}, \mathrm{CH}_{3}\right), 1.28\left(6 \mathrm{H}, \mathrm{s}, 2 \mathrm{CH}_{3}\right) .{ }^{13} \mathrm{C} \mathrm{NMR}$ (DMSO, $\left.300 \mathrm{MHz}\right)$ : $\delta 18.0,20.3,25.2,29.2,51.3,52.9,66.3,98.6,105.2,107.1$, 112.8, 118.6, 118.7, 119.5, 121.5, 125.5, 127.8, 132.2, 135.3, 135.50, 144.9, 147.2, 149.1, 149.6, 151.5, 165.3. Anal. calcd. (\%) for $\mathrm{C}_{30} \mathrm{H}_{31} \mathrm{~N}_{3} \mathrm{O}_{4}: \mathrm{C}, 72.41 ; \mathrm{H}, 6.28 ; \mathrm{N}, 8.44$. Found (\%) $\mathrm{C}$, 72.29; H, 6.26; N, 8.46.

1,3,3-Trimethyl-9' -( $p$-chlorobenzoyloxy)-6' -morpholino-spiro[indoline-2,3'(3H)naphtho[2,1-b][1,4]oxazine] (2e): Gray solid, yield: $50.7 \%$, m.p. $177-178{ }^{\circ} \mathrm{C}$. IR (KBr, $\left.V_{\max }, \mathrm{cm}^{-1}\right): 3049,2961,1624,1467,1360,1251,1117,1162$, 977, 847, 754, 745. ${ }^{1} \mathrm{H}$ NMR $\left(\mathrm{CDCl}_{3}, 500 \mathrm{MHz}\right): \delta 8.36(1 \mathrm{H}$, $\mathrm{d}, J=2.1 \mathrm{~Hz}, \mathrm{ArH}), 8.21(2 \mathrm{H}, \mathrm{d}, J=8.5 \mathrm{~Hz}, \mathrm{ArH}), 8.12(1 \mathrm{H}$, $\mathrm{d}, J=9.0 \mathrm{~Hz}, \mathrm{ArH}), 7.61\left(1 \mathrm{H}, \mathrm{s}, 2^{\prime}-\mathrm{H}\right), 7.52(2 \mathrm{H}, \mathrm{d}, J=8.5 \mathrm{~Hz}$, ArH), 7.25-7.21 (2H, m, ArH), 7.09 (1H, d, J=7.1 Hz, ArH), $6.89(1 \mathrm{H}, \mathrm{t}, J=7.4 \mathrm{~Hz}, \mathrm{ArH}), 6.61(1 \mathrm{H}, \mathrm{s}, \mathrm{ArH}), 6.58(1 \mathrm{H}, \mathrm{d}$, $J=7.7 \mathrm{~Hz}, \mathrm{ArH}), 3.95\left(4 \mathrm{H}, \mathrm{t}, J=4.4 \mathrm{~Hz}, \mathrm{CH}_{2}\right), 3.07(4 \mathrm{H}, \mathrm{t}$, $\left.J=4.4 \mathrm{~Hz}, \mathrm{CH}_{2}\right), 2.76\left(3 \mathrm{H}, \mathrm{s}, \mathrm{CH}_{3}\right), 1.36\left(3 \mathrm{H}, \mathrm{s}, \mathrm{CH}_{3}\right), 1.34$ $\left(3 \mathrm{H}, \mathrm{s}, \mathrm{CH}_{3}\right) .{ }^{13} \mathrm{C}$ NMR (DMSO, $\left.300 \mathrm{MHz}\right): \delta 20.3,25.2,29.2$, 51.3, 52.9, 66.3, 98.7, 105.4, 107.1, 112.9, 118.6, 119.5, 121.5, 121.6, 125.6, 127.8, 127.8, 129.1, 131.7, 132.2, 135.5, 138.9, 145.0, 147.2, 149.2, 149.5, 151.6, 163.9. Anal. calcd. (\%) for $\mathrm{C}_{33} \mathrm{H}_{30} \mathrm{ClN}_{3} \mathrm{O}_{4}$ : C, 69.77; H, 5.32; N, 7.40. Found (\%) C, 69.64; $\mathrm{H}, 5.31 ; \mathrm{N}, 7.42 \%$.

1,3,3-Trimethyl-6' -indolino-9' -methacryloyloxyspiro[indoline-2,3' $(3 H)$ naphtho[2,1-b][1,4] oxazine] (2f): Green crystal, yield: $51.3 \%$, m.p. 206-209 ${ }^{\circ} \mathrm{C}$. IR (KBr, $v_{\max }$, $\left.\mathrm{cm}^{-1}\right)$ : 3050, 2957, 2920, 1730, 1630, 1480, 1460, 1385, 1256, 1099, 1180, 1125, 977, 830, 744. ${ }^{1} \mathrm{H} \mathrm{NMR}\left(\mathrm{CDCl}_{3}, 500 \mathrm{MHz}\right)$ : $\delta 8.32(1 \mathrm{H}, \mathrm{d}, J=2.3 \mathrm{~Hz}, \mathrm{ArH}), 7.97(1 \mathrm{H}, \mathrm{d}, J=9.0 \mathrm{~Hz}, \mathrm{ArH})$, 7.64 (1H, s, 2'-H), 7.21-7.18 (2H, m, ArH), 7.10 (1H, t, $J=$ $2.3 \mathrm{~Hz}, \mathrm{ArH}), 7.06(1 \mathrm{H}, \mathrm{d}, J=3.6 \mathrm{~Hz}, \mathrm{ArH}), 6.92(1 \mathrm{H}, \mathrm{d}, J=$ $7.7 \mathrm{~Hz}, \mathrm{ArH}), 6.89-6.86(2 \mathrm{H}, \mathrm{m}, \mathrm{ArH}), 6.75(1 \mathrm{H}, \mathrm{t}, J=7.3 \mathrm{~Hz}$, ArH), $6.56(1 \mathrm{H}, \mathrm{d}, J=7.7 \mathrm{~Hz}, \mathrm{ArH}), 6.41(1 \mathrm{H}, \mathrm{s}, \mathrm{ArH}), 6.31$ $(1 \mathrm{H}, \mathrm{d}, J=7.9 \mathrm{~Hz}, \mathrm{ArH}), 5.78(1 \mathrm{H}, \mathrm{s}, \mathrm{ArH}), 3.90(2 \mathrm{H}, \mathrm{t}, J=$ $\left.8.5 \mathrm{~Hz}, \mathrm{CH}_{2}\right), 3.17\left(2 \mathrm{H}, \mathrm{t}, J=8.5 \mathrm{~Hz}, \mathrm{CH}_{2}\right), 2.76\left(3 \mathrm{H}, \mathrm{s}, \mathrm{CH}_{3}\right)$, $2.11\left(3 \mathrm{H}, \mathrm{s}, \mathrm{CH}_{3}\right), 1.34\left(6 \mathrm{H}, \mathrm{s}, \mathrm{CH}_{3}\right)$. Anal. calcd. (\%) for $\mathrm{C}_{34} \mathrm{H}_{31} \mathrm{~N}_{3} \mathrm{O}_{3}$ : C, 77.10; H, 5.90; N, 7.93. Found (\%) C, 76.98; H, 5.88; N, 7.95.

UV-VIS spectrophotometric measurements method: The solutions of 1a-1c and $\mathbf{2 a - 2 f}$ in different solvents (cyclohexane, dichloromethane and chloroform) with the concentration of $1 \times 10^{-5} \mathrm{~mol} \mathrm{~L}^{-1}$ were prepared. The UV-VIS absorption spectra was measured at $20^{\circ} \mathrm{C}$ in different solutions using a CARY 1101 UV-VIS spectrophotometer. The samples were irradiated with a $12 \mathrm{~W}$ ultraviolet lamp at $365 \mathrm{~nm}$ and the $\lambda_{\max }$ of the compounds were listed in Table- 1 . The fatigue resistance was examined after 150-cycle irradiation of UV and visible lights.

\section{RESULTS AND DISCUSSION}

Spirooxazine derivatives (1a-1c) were first prepared by the condensation reaction of 1,3,3-trimethyl-2-methyleneindoline with the ortho-hydroxynitroso aromatic derivatives in methanol, which further proceeded esterification with acyl chloride to give 2a-2f (Scheme-II). All the compounds were soluble in cyclohexane, dichloromethane, chloroform, methanol in varying degrees. FI-IR, ${ }^{1} \mathrm{H}$ NMR, ${ }^{13} \mathrm{C}$ NMR and elemental analyses on 1a-1c and $\mathbf{2 a - 2 f}$ confirmed the proposed structures.
TABLE-1

MAXIMUM ABSORPTION WAVELENGTH ${ }^{\mathrm{a}}$ OF 1a-1c AND 2a-2f

\begin{tabular}{cccc}
\hline \multirow{2}{*}{ Compound } & \multicolumn{3}{c}{ Solvent } \\
\cline { 2 - 4 } 1a & Cyclohexane & Dichloromethane & Chloroform \\
\hline 1b & 530.0 & 545.1 & 565.0 \\
1c & 540.0 & 550.0 & 584.9 \\
2a & 545.0 & 620.0 & 635.0 \\
2b & 540.0 & 565.1 & 575.1 \\
2c & 539.9 & 565.0 & 575.0 \\
2d & 550.0 & 564.9 & 575.0 \\
2e & 549.1 & 565.0 & 625.0 \\
2f & 560.0 & 560.0 & 619.9 \\
\hline
\end{tabular}

${ }^{a}$ Measured in various solvents $\left(\mathrm{c}=1 \times 10^{-5} \mathrm{~mol} \mathrm{~L}^{-1}\right)$ after irradiation at $365 \mathrm{~nm}$ with a $12 \mathrm{~W}$ ultraviolet lamp.

Absorption spectra of spiro compounds in various solvents after UV irradiation: The photoisomerization behaviour of the spirooxazine dyes were investigated by UVvisible analysis. UV irradiation of the compounds 1a-1c and 2a-2f at $365 \mathrm{~nm}$ led to an increase in absorption intensity in the visible region of the band at 530-665 nm, corresponding to the formation of the photomerocyanine form (Scheme-I). The absorption maxima $\left(\lambda_{\max }\right)$ of these open coloured forms measured in three different solvents (Table-1). We observed that spirooxazines 1a-1c and $\mathbf{2 a - 2 f}$ had different absorption $v_{\max }$ in different solvents (cyclohexane, dichloromethane, chloroform). With the increase in polarity of the solvent, the maximum absorbance of 1a-1c and 2a-2f underwent an obvious red shift. In the strongly polar solvents, the higher proportion of the merocyanine, the longer conjugate system in the ring-opened form which results in the red effects ${ }^{13}$. Compared to unsubstituted $\mathbf{1 a}$, heterocycle substituted $\mathbf{1 b}$ and 1c showed obviously red-shift and the absorption $\lambda_{\max }$ were found in the order of $\mathbf{1 c}>\mathbf{1 b}>\mathbf{1 a}$, with reference to earlier work $^{14}$, this was assigned to the electron-donating ability of 6'-substitutent on the naphthoxazine ring moiety. Thus, it presumably indicated that the electron-donating power of indolino $>$ morpholino which resulted in red effects. Compared to unesterificated $\mathbf{1 a}, \mathbf{1 b}$ and $\mathbf{1 c}$, esterificated $\mathbf{2 a}, \mathbf{2 d}$ and $\mathbf{2 f}$ showed varying degrees of red-shift, respectively as a result of $\pi$-electron delocalization arised from acyloxy moiety. 2a, $\mathbf{2 b}, \mathbf{2 c}$ showed nearly identical absorption in dichloromethane at the 565.1, 565.0 and $564.9 \mathrm{~nm}$ implying that 9'-acyloxy as a pendant had little effect on the absorption $\lambda_{\max }$. Preliminary results show that solvent and group linked as a pendant effects are responsible for these spectroscopic shifts and are intimately correlated.

Decoloration process of the coloured merocyanine form of spirooxazines in dichloromethane: The kinetics of the thermal decoloration were recorded on a spectrophotometer following the colour bleaching of the irradiated sample at $\lambda_{\max }$, immediately after switching off the ultraviolet lamp. Thermal decoloration of the compounds followed first order kinetics as the plots of $\left[\ln \left(\mathrm{A}_{\mathrm{t}}-\mathrm{A}_{\infty}\right) /\left(\mathrm{A}_{\mathrm{i}}-\mathrm{A}_{\infty}\right)\right]$ were linear and the slopes of the $\left[\ln \left(A_{t}-A_{\infty}\right) / \ln \left(A_{i}-A_{\infty}\right)\right]$ lines gave first order rate constants k. Kinetic runs were depicted in Figs. 1 and 2. The relaxation time of the photomerocyanines $\left(\tau_{\mathrm{MC}-\mathrm{sO}}\right)$ was obtained from the first order rate constant using the expression ${ }^{9}$ $\tau=1 / \mathrm{k}$. The corresponding values of $\mathrm{k}$ and $\tau_{\mathrm{MC}-\mathrm{so}}$ are given in 
<smiles>CCCC(C)C(C)C</smiles><smiles>C=C1N(CC)c2ccccc2C1(C)C</smiles><smiles>CN1c2ccccc2C(C)(C)C12C=Nc1c(cc(Br)c3ccc(O)cc13)O2</smiles><smiles>CN1c2ccccc2C(C)(C)C12C=Nc1c(cc(Br)c3ccc(O)cc13)O2</smiles><smiles>CCOc1ccc2c(c1)C(C)(C)C1(C=Nc3c(cc(Br)c4ccc(OCC)cc34)O1)N2C</smiles><smiles>C=C(C)C(=C)C</smiles>

Scheme-II: Synthesis of spirooxanzines (1a-1c and 2a-2f)

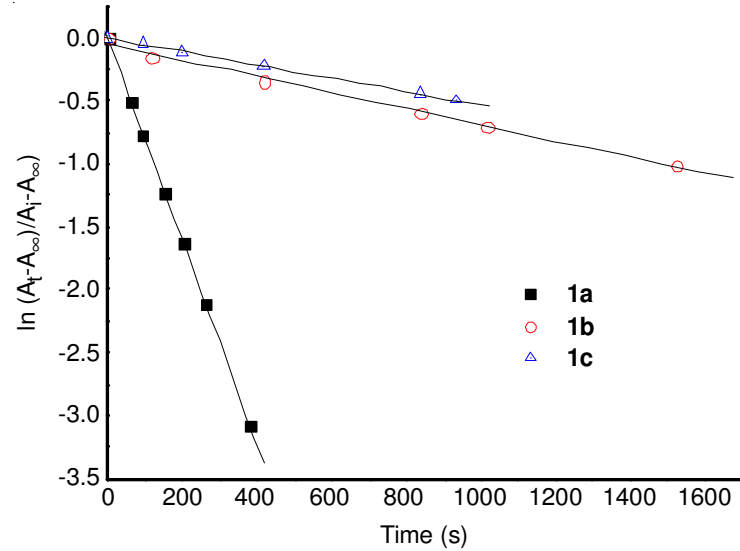

Fig. 1. Thermal relaxation of compounds 1a-1c in dichloromethane solutions $\left(1 \times 10^{-5} \mathrm{~mol} \mathrm{~L}^{-1}\right)$ after irradiation at $365 \mathrm{~nm}$ with a $12 \mathrm{~W}$ ultraviolet lamp

Table-2. According to these values, the rate of decoloration is influenced significantly by introducing morpholino and indolino substituent at 6 position of the spirooxazine. The $\tau_{\mathrm{MC}-\mathrm{So}}$ values of the photomerocyanines derived from $\mathbf{1 b}$ and 1c are 13 and 15 times larger than that of the unsubstituted compound 1a. Meanwhile, the decoloration process can also be influenced by replacing hydroxyl group by acyloxy group at the 9 ' position. For example, the $\tau_{\mathrm{Mc}-s o}$ value of photomerocyanines derived from esterificated compounds $\mathbf{2 a - 2} \mathbf{c}$ varied in a range of 190-204 s, suggesting a 2-fold increase than that

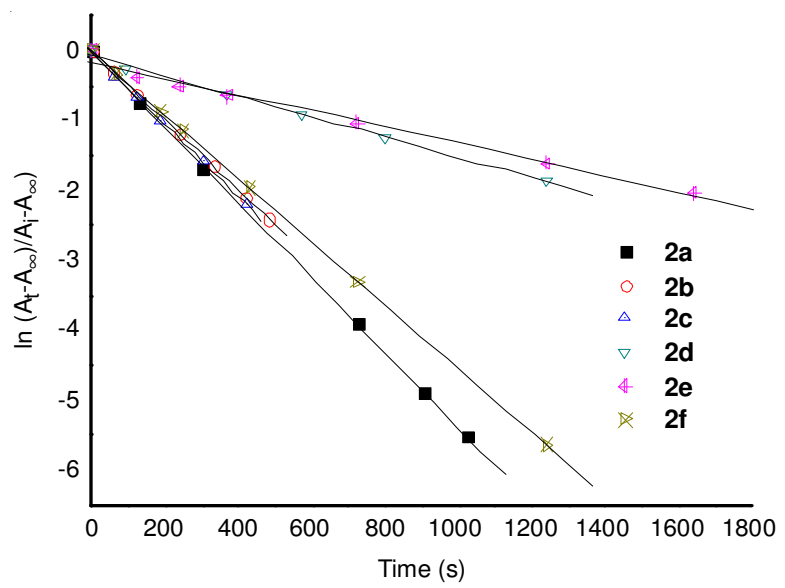

Fig. 2. Thermal relaxation of compounds $\mathbf{2 a - 2 f}$ in dichloromethane solutions $\left(1 \times 10^{-5} \mathrm{~mol} \mathrm{~L}^{-1}\right)$ after irradiation at $365 \mathrm{~nm}$ with a $12 \mathrm{~W}$ ultraviolet lamp

of unesterificated 1a. Furthermore, compared to the compound containing 6'-heterocycle, the relaxation time of the compounds containing both 6'-heterocycle and 9'-acyloxy decreases obviously in vary degrees. For example, the $\tau_{\mathrm{MC} \text {-so }}$ value of $\mathbf{2 e}$ decreases about 2 times than that of $\mathbf{1 b}$. The obtained results definitively show that $\tau_{\mathrm{MC}-\mathrm{so}}$ values vary gradually for 1a-1c and 2a-2f depending on electron-donating group and their position on the ring. Adjustable relaxation times (125-1886 s) were obtained by tuning heterocycle on 6 ' position and acyloxy on 9 ' position. Thus, we supposed that compounds with 
TABLE-2

RATE CONSTANTS $\mathrm{k}\left(\mathrm{s}^{-1}\right)$ OF THERMAL RING CLOSURE OF PHOTOMEROCYANINES DERIVED FROM COMPOUNDS 1a-1c AND 2a-2f AND THEIR LIFETIMES MC-SO (s) ${ }^{\mathrm{a}}$

\begin{tabular}{ccc}
\hline SO compound & Rate constants $\mathrm{k}^{-1} \mathrm{~s}^{-1}$ & Lifetimes $(\mathrm{s})$ \\
\hline $\mathbf{1 a}$ & 0.0080 & 125 \\
$\mathbf{1 b}$ & 0.00060 & 1667 \\
$\mathbf{1 c}$ & 0.00053 & 1886 \\
$\mathbf{2 a}$ & 0.0053 & 190 \\
$\mathbf{2 b}$ & 0.0049 & 204 \\
$\mathbf{2 c}$ & 0.0051 & 196 \\
$\mathbf{2 d}$ & 0.0014 & 714 \\
$\mathbf{2 e}$ & 0.0011 & 909 \\
$\mathbf{2 f}$ & 0.0046 & 217 \\
\hline
\end{tabular}

${ }^{\mathrm{a}}$ Measured in dichloromethane $\left(\mathrm{c}=1 \times 10^{-5} \mathrm{~mol} \mathrm{~L}^{-1}\right)$ after irradiation at $365 \mathrm{~nm}$ with a $12 \mathrm{~W}$ ultraviolet lamp. All measurements at $20^{\circ} \mathrm{C}$.

different $\tau_{\text {MC-so }}$ could be designed and synthesized by this method, which would lead to their successful use in various applications, such as eyewear, structural panel and recording films.

Photodegradation of of spirooxazines in the coloured merocyanine form in dichloromethane: the photodegradation was represented by a parameter $t_{\mathrm{A}_{0} / 2}$ which defined as the time in minute required to decrease the initial absorbance $\left(\mathrm{A}_{0}\right)$ at the $\lambda_{\max }$ of the merocyanine form to the half value $\left(\mathrm{A}_{0} / 2\right)$. Solutions of the compound 1a-1c and 2a-2f $\left(1.0 \times 10^{-5} \mathrm{~mol} \mathrm{~L}^{-1}\right)$ in dichloromethane were prepared. The solution was divided into 20 parts and all the parts were irradiated at the same time with a $12 \mathrm{~W}$ ultraviolet lamp. The absorbances (A) at $\lambda_{\max }$ in different irradiation time were recorded on a spectrophotometer after irradiation for photoequilibration. A typical example of the plot made for compound $\mathbf{2} \mathbf{f}$ is illustrated in Fig. 3. The $t_{\mathrm{A}_{0}}$ of $\mathbf{2 f}$ was calculated to be $420 \mathrm{~min}$.

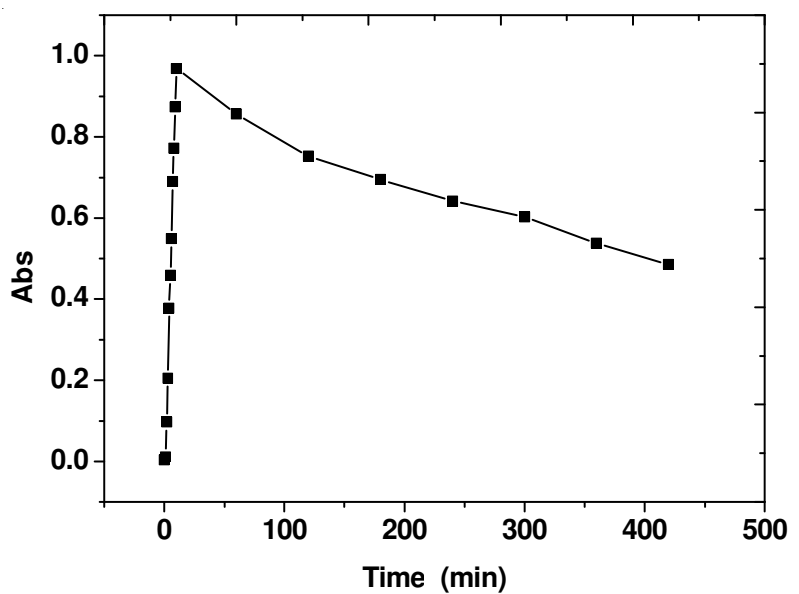

Fig. 3. Absorbance change at the $\lambda_{\max }$ of compound $2 \mathbf{f}\left(\lambda_{\max }=649.9 \mathrm{~nm}\right.$, $\mathrm{c}=1.0 \times 10^{-5} \mathrm{~mol} \mathrm{~L}^{-1}$
Fatigue resistance of spirooxazines in dichloromethane: The fatigue resistance was examined after 150-cycle irradiation of UV and visible lights. Compounds 1a-1c and 2a-2f were found to exhibit excellent fatigue resistance after repeated photocoloration. After 170-cycle irradiation, the absorbance was kept in $99.5 \%$. As it was analogized, the absorbance of the 1200-cycle would be kept in $96.6 \%\left(A=A_{0}(1-X)^{n}, A_{0}\right.$ : the initial absorbance; $X$ : the variational absorbance; $n$ : cycle times). It was shown that spirooxazines containing heterocycle on 6' position and acyloxy on 9' position exhibited excellent stability.

\section{Conclusion}

A series of novel 1,3,3-trimethyl spiro [2H]-indol-2,3'$[3 H]$ - naphtho[2,1-b][1,4]oxazine derivatives were synthesized and characterized. All the compounds exhibited excellent photochromism upon UV irradiation in solutions. Furthermore, an efficient method to adjust relaxation time was demonstrated by the structural modification on 6'-heterocycle and 9'-acyloxy. It is hoped that a series of spirooxazines with different and acceptable relaxation time can be synthesized by further investigating structure-property relationships.

\section{ACKNOWLEDGEMENTS}

The authors acknowledged Industrialization of Scientific Research Promotion Projects of Colleges and Universities in Jiangsu Province for financial support.

\section{REFERENCES}

1. V.A. Lokshin, A. Samat and A.V. Metelitsa, Russ. Chem. Rev., 71, 893 (2002).

2. N. Alhashimy, R. Byrne, S. Minkovska and D. Diamond, Tetrahedron Lett., 50, 2573 (2009).

3. Y.A. Son, Y.M. Park, M.S. Choi and S.H. Kim, Dyes Pigments, 75, 279 (2007).

4. D. Gust, T.A. Moore and A.L. Moore, Chem. Commun., 1169 (2006).

5. H. Tian and S.J. Yang, Chem. Soc. Rev., 33, 85 (2004).

6. S. Kawata and Y. Kawata, Chem. Rev., 100, 1777 (2000).

7. T. Deligeorgiev, S. Minkovska, B. Jeliazkova and S. Rakovsky, Dyes Pigments, 53, 101 (2002).

8. G. Berkovic, V. Krongauz and V. Weiss, Chem. Rev., 100, 1741 (2000).

9. S. Minkovska, B. Jeliazkova, E. Borisova, L. Avramov and T. Deligeorgiev, J. Photochem. Photobiol. A, 163, 121 (2004).

10. P. Rys, R. Weber and Q.L. Wu, Can. J. Chem., 71, 1828 (1993).

11. E.U. Kulawardana, T. Kuruwita-Mudiyanselage and D.C. Neckers, J. Polym. Sci. A: Polym. Chem., 47, 3318 (2009).

12. H. Dürr, Y. Ma and G. Corterllaro, Synthesis, 294 (1995).

13. T.F. Tan, P.L. Chen, H.M. Huang and J.B. Meng, Tetrahedron, 61, 8192 (2005).

14. M. Rickwood, S.D. Marsden, M.E. Ormsby, A.L. Staunton and D.W. Wood, Mol. Cryst. Liq. Cryst., 246, 17 (1994). 